\title{
RESPONSIVITAS DINAS PENANAMAN MODAL PELAYANAN TERPADU SATU PINTU DAN TENAGA KERJA KOTA BATU TERHADAP TINGGINYA TINGKAT PENGANGGURAN DI KOTA WISATA BATU
}

\author{
Retno Wulan Sekarsari \\ Program Studi Ilmu Administrasi Publik, Fakultas Ilmu Administrasi, Universitas Islam Malang \\ retnowulansekarsari@gmail.com \\ Maulidina Ainur Rosida \\ Program Studi Ilmu Administrasi Publik, Fakultas Ilmu Administrasi, Universitas Islam Malang
}

\begin{abstract}
Abstrak
Tujuan dari penelitian ini adalah untuk mengetahui penyebab dan dampak tingginya tingkat pengangguran di kota wisata batu, serta upaya atau respon pemerintah kota batu dalam menangani masalah tingginya tingkat pengangguran tersebut. Tingginya tingkat pengangguran di Kota Wisata Batu di sebabkan oleh beberapa faktor, yaitu : pendidikan yang rendah, kurangnya ketrampilan, kurang efektifnya informasi pasar kerja bagi para pencari kerja, kurangnya tingkat EQ masyarakat, kurangnya sosialisasi tentang ketenagakerjaan, pola pikir masyarakat dalam mendapatkan pekerjaan, rasa malas dan ketergantungan diri pada orang lain. Disisi lain, tingginya tingkat pengangguran juga berdampak bagi masyarakat, yaitu beban psikologis, menimbulkan ketidakstabilan antara sosial dan politik, menghilangkan keterampilan individu, menghilangkan mata pencaharian dan pendapatan individu. Untuk mengurangi tingkat pengangguran, maka harus ada dari Pemerintah dan Dinas Penanaman Modal Pelayanan Terpadu Satu Pintu dan Tenaga Kerja Kota Wisata Batu. Respon dan upaya-apaya Pemerintah Kota Batu dalam menangani masalah tingginya tingkat pengangguran di Kota Wisata Batu yaitu: dengan direncanakan dan diadakannya "Kegiatan Pembinaan dan Pelatihan Ketrampilan Kerja bagi Tenaga Kerja dan Masyarakat" oleh Dinas Penanaman Modal Pelayanan Terpadu Satu Pintu dan Tenaga Kerja Kota Wisata Batu, dijalinnya hubungan kerja sama antara Dinas Sosial dan Tenaga Kerja Kota Batu dengan Disperindag, Kegiatan Pembinaan Pelayanan Penempatan Tenaga Kerja Antar Daerah (AKAD) dan Antar Kerja Lokal (AKL), Motivasi dan Manajemen Usaha Mandiri Sektor Informal, dan job market fair atau pameran bursa kerja yang digelar oleh Dinas Sosial dan Tenaga Kerja Kota Batu.
\end{abstract}

Kata Kunci: Responsivitas, Disnakertrans, Pengangguran, Kota Batu

\begin{abstract}
This research aims to learn about the causes and impacts of high unemployment rate in Batu City as well as efforts or responses of the Municipal to overcome this issue. The high unemployment rate in Batu City is caused by several factors, namely: low-level of education, lack of skills, ineffective distribution of information on job market for job seekers, relatively low EQ level, lack of socialization on workforce, the general mindset in obtaining jobs, laziness and dependency to others. On the other hand, the high unemployment rate also affects the society in the forms of psychological burden, political and social instability, omission of individual skills, livelihood and income. To reduce the rate of unemployment, there must be efforts and responses from the Municipal, via the Office of Integrated Investment Services and Workforce of the Batu Municipal, to tackle this issue of high unemployment rate in Batu City, such as: planning and organizing "Work Skill Training and Development Activity for Workforce and Society" by the Office of Integrated Investment Services and Workforce, establishing cooperation between the Social Issues and Workforce Office and the Industry and Trade Office, organizing Inter-District and Local InterWork Workforce Placement Service Development, Motivation and Management of Informal Sector Entrepreneusrship, and job fairs organized by the Social and Workforce Office of Batu City.
\end{abstract}

Keywords: Responsivity, Workforce and Transmigration Office, Unemployment, Batu City. 


\section{PENDAHULUAN}

Dalam rangka mewujudkan good governance di Indonesia maka perlu dikembangkan dalam penyelenggaraan pelayanan publik yang mencirikan karakteristik yang selama ini melekat dalam diri good governance. Karakteristik tersebut seperti efesiensi, transparasi, akutanbilitas, respontabilitas dan responsivitas dapat dijelaskan secara relatif mudah dalam penyelenggaraan pelayanan publik (Agus Dwiyanto, 2005:147) ${ }^{1}$.

Responsivitas sebagai salah satu karakteristik good governance sangat diperlukan dalam penyelenggaraan pelayan publik. Responsivitas adalah kemampuan birokrasi untuk mengenali kebutuhan masyarakat,menyusun agenda dan prioritas pelayanan, serta mengembangkan program-program pelayanan sesuai dengan kebutuhan dan aspirasi masyarakat.

Di era globalisasi masalah pelayanan publik saat ini sedang banyak dibicarakan masyarakat terutama untuk meningkatkan taraf hidup masyarakat. Dalam UU No. 25 tahun 2009 tentang pelayanan publik, dijelaskan masyarakat berhak mendapatkan pelayanan yang berkualitas sesuai dengan asas dan tujuan pelayanan (pasal 18) ${ }^{2}$. Pelayanan publik dapat menyangkut bidang kesejahteraan sosial, pendidikan, kesehatan, transportasi, kebutuhan pangan pokok, dan masih banyak lagi. Oleh karena itu, responsivitas pemerintah dalam salah satu perwujudan good governance harus mencakup seluruh kepentingan publik termasuk kesejahteraan sosial dan ketenagakerjaan.

Salah satu masalah pokok yang sedang dihadapi pemerintah Kota Batu pada bidang kesejahteraan sosial adalah masalah tingginya tingkat pengangguran. Pengangguran merupakan suatu ukuran yang dilakukan jika dalam kegiatan produktif yaitu menghasilkan barang dan jasa. Angkatan kerja ini terdiri dari golongan yang bekerja dan golongan yang menganggur. Golongan yang bekerja (employed persons) merupakan sebagian masyarakat yang sudah aktif dalam kegiatan yang menghasilkan barang dan jasa. Sedangkan sebagian masyarakat lainnya yang tergolong siap bekerja dan mencari pekerjaan termasuk dalam golongan menganggur.

Pengangguran di Kota Wisata Batu menimbulkan beberapa dampak, seperti beban psikologis, ketidakstabilan antara sosial dan politik, keterampilan individu, menghilangkan mata pencaharian dan

\footnotetext{
${ }^{1}$ Niken Irmawati, "Responsivitas Pemerintah Kota Surakarta Terhadap Perlindungan Anak Menuju Solo Kota Layak Anak (KLA)", diakses dari https://core.ac.uk/download/pdf/12347933.pdf, pada tanggal 07 Oktober 2017 pukul 09:30 WIB

2 "Responsivitas Pelayanan Publik (Studi Kasus Pelayanan Kesehatan Rawat Inap Rumah Sakit Sayang Rakyat Kota Makassar)”, diakses dari http://core.ac.uk/download/pdf/77620716.pdf, pada tanggal 07 Oktober 2017 pukul 09:14 WIB
}

pendapatan individu, dan lain-lain. Tingginya tingkat pengangguran di Kota Wisata Batu disebabkan oleh beberapa faktor, yaitu: pendidikan rendah, kurangnya kemampuan yang dimiliki, kurang efektifnya informasi pasar kerja bagi para pencari kerja, kurangnya tingkat EQ masyarakat, dan lain sebagainya.

Maka dari itu pemerintah Kota Batu harus turun tangan untuk menangani permasalahan tersebut guna meminimalisir tingginya angka pengangguran dan dampaknya baik terhadap masyarakat dan pemerintah Kota Batu sendiri. Dinas Penanaman Modal Pelayanan Terpadu Satu Pintu dan Tenaga Kerja Kota Batu mencanangkan beberapa program, yaitu diadakannya sosialisasi, pelatihan ketenagakerjaan bagi masyarakat untuk mengurangi dan menekan tingginya angka pengangguran di Kota Batu.

Jurnal ini akan membahas beberapa rumusan masalah, yaitu: penyebab dan dampak tingginya tingkat pengangguran di Kota Wisata Batu, serta upaya dan respon Pemerintah Kota dalam menangani permasalhan tersebut.

\section{Responsivitas dalam Good Governance}

UNDP (1997) dalam Serdarmayanti (2004:247) mengemukakan karakteristik atau prinsip yang harus dianut dan kembangkan dalam praktek penyelenggarakan kepemerintah yang baik, meliputi participation, rule of law, transparency, responsivennes, consensus orientation, equity, effectiveness, and efficiency, accountability, strategic vision. Atas dasar uraian tersebut, maka dapat disimpulkan bahwa wujud good governance adalah penyelenggaraan pemerintah Negara yang bertanggung jawab serta efesien dan efektif.

Dengan demikian, responsivitas merupakan salah satu karakteristik good governance. Lenvine dalam Agus Dwiyanto (2005:147), produk dari pelayanan publik di dalam Negara demokratis paling tidak harus memenuhi tiga indikator, yakni responsiveness, responsibility dan accountability. Responsivitas yang merupakan good governance adalah kemampuan untuk mengidentifikasi kebutuhan masyarakat, menyusun prioritaskan kebutuhan, dan mengembangkan kedalam berbagai program pelayanan. Responsivitas mengukur daya tanggap organisasi terhadap harapan, keinginan, dan aspirasi, serta tuntutan warga pengguna layanan. Tujuan utama pelayanan publik adalah memenuhi kebutuhan warga pengguna agar dapat memperoleh pelayanan yang diinginkan dan memuaskan. Indikator responsivitas pelayanan publik adalah penanganan yang tanggap, cepat dan akurat dalam menyikapi keluhan pengguna jasa oleh aparat birokrasi sebagai referensi perbaikan layanan 
publik, perbaikan birokrasi dalam sistem pelayanan yang berlaku (Irmawati, 2002:60-61) ${ }^{3}$.

Tugas Pokok Dan Fungsi Dinas Penanaman Modal Pelayana Terpadu Satu Pintu dan Tenaga Kerja Kota Wisata Batu

Berdasarkan Peraturan Walikota Batu Nomor 75 Tahun 2016 Tentang Kependudukan, Susunan Organisasi, Uraian Tugas dan Fungsi, Serta Tata Kerja Dinas Penanaman Modal Pelayanan Terpadu Satu Pintu dan Tenaga Kerja Kota Batu mempunyai tugas membantu Walikota melaksanakan urusan pemerintahan yang menjadi kewenangan daerah di bidang penanaman modal. pelayanan perijinan, dan urusan pemerintahan bidang tenaga kerja ${ }^{4}$.

Dinas Penanaman Modal Pelayanan Terpadu Satu Pintu dan Tenaga Kerja Kota Batu menyelenggarakan fungsi : (1) perumusan kebijakan teknis dan rencana strategis di bidang penanaman modal, pelayanan perijinan, dan urusan pemerintahan bidang tenaga kerja; (2) penetapan rencana kerja dan anggaran di bidang penanaman modal, pelayanan perijinan, dan urusan pemerintahan bidang tenaga kerja; (3) melaksanakan kebijakan di bidang penanaman modal, pelayanan perijinan, dan urusan pemerintahan bidang tenaga kerja; (4) penyelenggarana peningkatan kualitas Sumber Daya Manusia aparatur di bidang penanaman modal, pelayanan perijinan, dan urusan pemerintahan bidang tenaga kerja; (5) pelaksanaan administrasi dinas di bidang penanaman modal, pelayanan perijinan, dan urusan pemerintahan bidang tenaga kerja; (6) penyelenggaran evaluasi pelaksanaan program, kegiatan, dan anggaran di bidang penanaman modal, pelayanan perijinan, dan urusan pemerintahan bidang tenaga kerja; dan (7) pelaksanaan fungsi lain yang diberikan oleh Walikota terkait dengan tugas dan fungsinya.

\section{Peran Dinas Penanaman Modal Pelayanan Terpadu Satu Pintu dan Tenaga Kerja Kota Wisata Batu}

Sasaran yang ingin dicapai Badan Penanaman Modal Kota Batu berpijak pada prinsip "SMART" yaitu: Specific (vital), Measurable (dapat diukur), Achievable (dapat dicapai), Result Oriented (berorientasi pada hasil/ manfaat), Time Bond Time Related (jangka waktu), sehingga sasaran yang dituju adalah: (1) meningkatnya

\footnotetext{
${ }^{3}$ Niken Irmawati, "Responsivitas Pemerintah Kota Surakarta Terhadap Perlindungan Anak Menuju Solo Kota Layak Anak (KLA)", diakses dari https://core.ac.uk/download/pdf/12347933.pdf, pada tanggal 07 Oktober 2017 pukul 13:42 WIB

4 “Tupoksi Dinas Penanaman Modal Pelayanan Terpadu Satu Pintu dan Tenaga Kerja Kota Wisata Batu”, Dinas Penanaman Modal Pelayanan Terpadu Satu Pintu dan Tenaga Kerja Kota Wisata Batu,diakses dari http://bpm.batukota.go.id/dpmptsptk/index.php/web/kontent/38/tupoksi ,pada tanggal 14 Oktober 2017 pukul 07:32 WIB
}

kualitas pelayanan publik kepada masyarakat; (2) Meningkatnya realisasi investasi daerah melalui iklim usaha yang kondusif bagi penanaman modal daerah; dan (3) Meningkatnya partisipasi / kesadaran masyarakat dalam kepemilikan izin ${ }^{5}$.

\section{METODE PENELITIAN \\ Jenis Penelitian}

Penelitian merupakan sarana untuk memahami suatu permasalahan secara ilmiah dengan menggunakan metode tertentu yang dipilih sesuai dengan permasalahan yang diteliti. Dalam penelitian ini, peneliti menggunakan jenis penelitian deskriptif - kualitatif. Hybert Hyman dalam Koentjaraningrat (1991:29) mengartikan jenis penelitian yang bersifat deskriptif adalah penelitian yang bersifat deskriptif adalah penelitian yang mempunyai tujuan untuk menggambarkan secara tepat tentang sifatsifat suatu individu, keadaan, gejala, atau kelompokkelompok tertentu atau untuk menentukan frekuensi adanya hubungan tertentu antara suatu gejala atau frekuensi adanya hubungan tertentu antara suatu gejala dengan gejala lain di masyarakat. Sedangkan metode penelitian kualitatif sesuai dengan yang dikemukakan oleh Bogdan dan Taylor dalam Moleong (2002:3) bahwa metode kualitatif didefinisikan sebagai prosedur penelitian yang menghasilkan data deskriptif berupa kata-kata tertulis atau lisan dari orang-orang dan perilaku yang dapat diamati.

\section{Teknik Pengumpulan Data}

Teknik pengumpulan data adalah cara-cara yang dapat digunakan oleh peneliti untuk mengumpulkan data (Arikunto, 1990:134). Dalam penelitian ini, pengumpulan data dilakukan dengan menggunakan beberapa cara, yakni sebagai berikut:

a. Studi kepustakaan, dilakukan dengan cara melakukan pengumpulan data dari beberapa referensi yang berkaitan dengan hal yang diteliti. Dengan mengumpulkan berbagai data dari kantor Dinas Penanaman Modal Pelayanan Terpadu Satu Pintu Dan Tenaga Kerja Kota Batu, maka peneliti mencoba mempelajari serta menganalisis data/fakta dari literatur-literatur yang relevan dengan masalah penelitian.

b. Studi lapangan, menggunakan teknik-teknik pengumpulan data sebagai berikut: Pertama, observasi yaitu pengamatan obyek secara langsung ke Dinas Penanaman Modal Pelayanan Terpadu Satu Pintu Dan Tenaga Kerja Kota Batu, serta lokasi-lokasi tempat

\footnotetext{
5 "Tujuan dan Sasaran Dinas Penanaman Modal Pelayanan Terpadu Satu Pintu dan Tenaga Kerja Kota Wisata Batu”, diakses dari http://bpm.batukota.go.id/dpmptsptk/web/kontent/15/tujuan_dan_sasara $\underline{\mathrm{n}}$, pada tanggal 14 Oktober 2017, pukul 16:18 WIB
} 
dilaksanakannya job fair, dan pelatihan tenaga kerja oleh dinas terkait dan Pemerintah Kota Batu. Kedua, wawancara yaitu dialog yang dilakukan peneliti secara langsung kepada masyarkat yang ikut serta dalam job fair dan pelatihan, serta staf Dinas Penanaman Modal Pelayanan Terpadu Satu Pintu Dan Tenaga Kerja Kota Batu untuk memperoleh informasi yang diperlukan. Ketiga, dokumentasi yaitu metode yang dilaksanakan denga cara mengadakan pencatatan terhadap dokumen-dokumen dan pengambilan gambar mengenai hal-hal yang diteliti, khususnya tentang responsivitas Dinas Penanaman Modal Pelayanan Terpadu Satu Pintu Dan Tenaga Kerja Kota Batu terhadap tingginya tingkat pengangguran di Kota Wisata Batu

\section{Instrument Penelitian}

Instrument penelitian dapat didefinisikan sebagai suatu alat yang digunakan oleh ahli analisis untuk mensistematiskan pengumpulan data (Mayer and Greenwood, 1984:399). Instrumen penelitian yang baik harus memenuhi persyaratan penting yaitu, valid dan reliabel. Berikut instrument penelitian yang dipergunakan peneliti dalam memperoleh data dan informasi dalam penelitian ini: (a) Peneliti sendiri, melalui observasi dengan lingkungan/instansi terkait dan melakukan wawancara serta dokumentasi terhadap obyek sasaran. (b) Pedoman wawancara, yaitu pertanyaan tertulis yang disusun secara terstruktur untuk mendapatkan data yang akurat berupa tanggapan terhadap suatu fenomena atau masalah yang akan diteliti. (c) Catatan lapangan (Field Note), yaitu sebagai sarana/alat yang digunakan oleh peneliti dalam mencatat seluruh informasi terkait hasil observasi dan pengamatan yang diperoleh peneliti selama berlangsungnya proses penelitian di lapangan.

\section{Analisis Data}

Metode analisis yang dipergunakan oleh peneliti adalah deskriptif-kualitatif. Analisis data dimulai dengan membaca, mempelajari dan menelaah data yang telah dikumpulkan, selanjutnya mengadakan penyusunan, pengolahan dan interpretasi data untuk kemudian ditarik suatu kesimpulan. Proses pengimplementasian datanya dengan menggambarkan atau mendeskripsikan data yang diperoleh sesuai dengan latar alamiah yang disampaikan dengan cara menyusunnya. Data yang diperoleh ini selanjutnya dianalisis mengikuti langkah-langkah sebagaimana disarankan oleh Miles dan Huberman (1992:18-21), meliputi: reduksi data, penyajian data, kesimpulan dan verifikasi.

1. Reduksi data (Data reduction). Merupakan proses merangkum, mengikhtisarkan, atau menyeleksi data dari catatan lapangan yang kemudian dimasukkan dalam kategori tema yang mana, fokus atau permasalahan yang mana yang sesuai dengan fokus penelitian.

2. Penyajian data (Data display). Merupakan proses penyajian data ke dalam sejumlah matriks yang sesuai dan yang berfungsi untuk memetakan data yang telah direduksi, juga untuk memudahkan mengkonstruksikan didalam rangka menyimpulkan dan menginterpretasikan data.

3. Penarikan kesimpulan (Conclusing drawing). Membuat suatu kesimpulan dari makna-makna yang muncul dari data yang harus diuji kebenaran, kekokohan, dan kecocokannya.

\section{Lokasi dan Waktu Penelitian}

Penelitian ini berlokasi di Kota Wisata Batu, khususnya di Dinas Penanaman Modal Pelayanan Terpadu Satu Pintu Dan Tenaga Kerja Kota Batu. Penelitian ini dilakukan dan difokuskan untuk mengetahui penyebab dan dampak tingginya tingkat pengangguran di Kota Wisata Batu, serta upaya atau respon pemerintah Kota Batu dalam menangani masalah tingginya tingkat pengangguran tersebut.

Penelitian ini kurang lebih dilakukan dalam jangka 1 (semester) atau 6 bulan (di hari aktif). Pada bulan pertama dilakukan persiapan perijinan dan penyusunan instrument sebagai kelengkapan dalam proses penelitian lapangan. Kemudian pada bulan kedua dan ketiga, dilakukan survey secara mendalam dan menyeluruh terhadap aspek yang diteliti. Selanjutnya dalam bulan ketiga dilakukan analisis terhadap data yang diperoleh. Pada bulan keempat dan kelima, dilakukan diagnosis dari hasil analisis lapangan, dan dilanjutkan dengan wawancara mendalam terhadap masyarakat dan staf Dinas Penanaman Modal Pelayanan Terpadu Satu Pintu Dan Tenaga Kerja Kota Batu guna melengkapi data sebagai bahan analis pada bulan yang sama. Kemudian, melakukan pengumpulan data skunder pada bulan kelima dan keenam, dilanjutkan dengan melakukan analisis data.

Tabel. 1: Jadwal Kegiatan Penelitian

\begin{tabular}{|c|c|c|c|c|c|c|c|c|c|c|}
\hline \multirow{2}{*}{ KEGIATAN } & \multicolumn{10}{|c|}{ BULAN KE } \\
\hline & 1 & 2 & 3 & 4 & 5 & 6 & 7 & 8 & 9 & 10 \\
\hline \multicolumn{11}{|l|}{ Persiapan perijinan dan } \\
\hline \multicolumn{11}{|l|}{ Penyusunan } \\
\hline \multicolumn{11}{|l|}{ Instrumen penelitian } \\
\hline \multicolumn{11}{|l|}{$\begin{array}{l}\text { Survey terhadap aspek } \\
\text { yang diteliti }\end{array}$} \\
\hline \multicolumn{11}{|l|}{ Analisis kesesuaian } \\
\hline \multicolumn{11}{|l|}{ implementasi kebijakan } \\
\hline \multicolumn{11}{|l|}{ pembangunan jalan dan } \\
\hline \multicolumn{11}{|l|}{ kendala-kendala yang } \\
\hline \multicolumn{11}{|l|}{ dihadapi } \\
\hline \multirow{2}{*}{\multicolumn{11}{|c|}{$\begin{array}{l}\text { Diagnosis hasil analisis } \\
\text { lapangan }\end{array}$}} \\
\hline & & & & & & & & & & \\
\hline \multicolumn{11}{|l|}{ Wawancara medalam } \\
\hline
\end{tabular}




\begin{tabular}{l}
\hline $\begin{array}{l}\text { Pengumpulan data } \\
\text { skunder }\end{array}$ \\
\hline $\begin{array}{l}\text { Melakukan analisis data } \\
\text { yang diperoleh }\end{array}$ \\
\hline Penyusunan laporan \\
\hline
\end{tabular}

HASIL DAN PEMBAHASAN

\section{Faktor Penyebab Tingginya Tingkat Pengangguran di Kota Wisata Batu}

Tingginya tingkat pengangguran di Kota Wisata Batu dikutip oleh suryamalang.com ${ }^{6}$

SURYAMALANG.COM, BATU - Sampai Bulan September 2016, jumlah pengangguran di Kota Batu mencapai 4.700 orang sesuai data BPS.

Mereka terbagi menjadi dua kategori, yakni tenaga kerja pasif mencapai 4.000 orang dan tenaga kerja aktif sebanyak 700 orang.

Kutipan diatas merupakan bukti dari tingginya tingkat pengangguran di Kota Wisata Batu yang dinyatakan oleh Kabid Pengembangan dan Penempatan Tenaga Kerja Dinsosnaker, Alfian Hafny.

Pengangguran terbuka adalah tenaga kerja yang betul-betul tidak mempunyai pekerjaan. Pengangguran ini terjadi ada yang karena belum mendapat pekerjaan padahal telah berusaha secara maksimal dan ada juga yang karena malas mencari pekerjaan atau malas bekerja ${ }^{7}$.

Gambar. 1: Tingkat Pengangguran Terbuka (TPT)

\begin{tabular}{|c|c|c|c|c|c|}
\hline \multirow{2}{*}{ Wlayah } & \multicolumn{5}{|c|}{ Tnakat Penganeauran Terbuka (Persen) } \\
\hline & 2011 & 2012 & 2013 & 2014 & 2015 \\
\hline Kabupaten Sunenep & 1.99 & 1.14 & 256 & 101 & 207 \\
\hline Kota Kediri & 9.69 & 8.12 & 7.92 & 7.66 & 8.46 \\
\hline Kota Blitar & 524 & 3.68 & 6.17 & 5.71 & 3.80 \\
\hline Kota Malang & 9.74 & 7.96 & 7.73 & 7.22 & 7.28 \\
\hline Kolta Probolinggo & 5.46 & 5.26 & 4.48 & 5.16 & 4.01 \\
\hline Kota Pasuruan & 6.22 & 4.54 & 5.41 & 6.09 & 5.57 \\
\hline Kota Mojokerto & 10.59 & 7.52 & 5.73 & 4.42 & 4.88 \\
\hline Kota Madiun & 10.62 & 6.89 & 6.57 & 6.93 & 5.10 \\
\hline Kota Surabaya & 781 & 527 & 532 & 582 & 701 \\
\hline Kota Batu & 4.82 & 3.51 & 2.30 & 2.43 & 4.29 \\
\hline
\end{tabular}

Sumber: Badan Pusat Statistik Jatim Pengangguran Terbuka $^{8}$

Di Kota Wisata Batu, Tingkat Pengangguran Terbuka (TPT) dari tahun 2011-2013 mengalami penurunan yang signifikan dan pada tahun 2013-2014 Tingkat Pengangguran Terbuka (TPT) mengalami sedikit

${ }^{6}$ Ahmad Amru Muiz dan Eko Darmoko, " 4 Ribu Warga Batu Masih Jadi Pengangguran Pasif”, Surya Malang , diakses dari http://suryamalang.tribunnews.com/amp/2016/09/27/4-ribu-warga-batumasih-jadi-pengangguran-pasif, pada tanggal 06 Oktober 2017 pukul 21:01 WIB

7“Abstraksi Ekonomi Teori, Jenis dan Faktor Penyebab Pengangguran", faisalbasri01 diakses dari http://abstraksiekonomi.blogspot.co.id/2014/10/teori-jenis-dan-faktorpenyebab.html?m=1, pada tanggal 06 Oktober 2017 pukul 08:17 WIB

8 "Tenaga Kerja-BPS Provinsi Jawa Timur" diakses dari http://jatim.bps.go.id/Subjek/view/id/6 , pada tanggal 06 Oktober 2017 pukul 20:13 WIB peningkatan dari $2.30 \%$ menjadi $2.43 \%$. Sedangkan pada tahun 2014-2015 Tingkat Pengangguran terbuka meningkat secara drastis dari $2.43 \%$ menjadi $4.29 \%$. (Sumber: Badan Pusat Statistik Jatim Pengangguran Terbuka)

Meskipun pada tabel diatas menjelaskan bahwa Tingkat Pengangguran Terbuka pada tahun 2011 lebih besar daripada tahun 2015 semata-mata tingkat pengangguran di Kota Batu mengalami penurunan. Tetapi pada kenyataanya tingkat pengangguran terbuka di Kota Batu sangat tinggi karena pada tahun 2011 Kota Batu masih dalam tahap perkembangan dan pembangunan dalam bidang kepariwisataan. Sedangkan pada tahun 2015 Kota Wisata Batu sudah melewati tahap perkembangan dan pembangunan khususnya di bidang kepariwisataan, apalagi bila dibandingkan dengan sekarang. Hal ini di buktikan semakin banyak tempat pariwisata dan banyaknya penginapan seperti halnya hotel, villa, homestay dan lain-lain. Seharusnya adanya kemajuan dalam perkembangan dan pembangunan di Kota Wisata Batu harus berbanding lurus dengan rendahnya tingkat pengangguran di Kota Wisata Batu, karena dengan seiringnya banyaknya tempat wisata seharusnya juga banyak tingkat kesempatan kerja atau peluang kerja bagi para penganggur di Kota Wisata Batu. Namun pada realitanya tingkat pengangguran tahun 2015 yang mana Kota Wisata Batu sudah banyak kemajuan atas perkembangan dan pembangunannya pariwisata lebih tinggi daripada tingkat pengangguran tahun 2011 yang pada masa masih tahap perkembangan dan pembangunan "Kota Wisata” Batu (KWB).

Beberapa faktor penyebab tingginya tingkat pengangguran di Kota Wisata Batu, antara lain :

1. Pendidikan Rendah. Pendidikan yang rendah dapat menyebabkan seseorang kesulitan dalam mencari pekerjaan, karena kebanyakan semua instansi/perusahaan membutuhkan pegawai seminimal SMA. Dalam hal ini masyarakat Kota Batu akan kalah saing dalam mencari pekerjaan khususnya di daerah luar Kota Batu. Tentunya suatu pekerjaan pasti akan memilih orang-orang yang mempunyai wawasan atau pengetahuan yang luas dan mempunyai banayak pengalaman. 
2. Kurangnya Keterampilan. Faktor lain penyebab pengangguran adalah kurangnya ketrampilan. Hal ini juga dilansir oleh Beritajatim.com ${ }^{9}$

Kepala Dinas Sosial dan Tenaga Kerja Kota Batu, Eko Suhartono mengatakan, data ribuan warga pengangguran tersebut berasal dari Badan Pusat Statistik (BPS) Kota Batu. Menurutnya, adanya pengangguran tersebut disebabkan oleh berbagai faktor. "Mayoritas warga yang belum memiliki pekerjaan karena permasalahan pendidikan dan kurangnya kemampuan yang dimiliki," kata Eko Suhartono, Rabu (11/6/2014).

Sebenarnya jika dilihat dari tahun ketahun pendidikan di Kota Batu juga semakin meningkat secara perlahan, banyak mahasiswa atau lulusan SMA yang sudah mempunyai kriteria dalam bekerja ,namun dalam teknisnya keterampilannya masih kurang. Sehingga susah dalam mencari pekerjaan. Kurangnya keterampilan ini merupakan dampak yang berkesinambungan atau berkaitan dengan dampak pendidikan rendah diatas, karena dalam dunia pendidikan siswa/mahasiwa pasti belajar akademik dan non akademik, serta mengasah bakat dan keterampilan. Maka dari itu, dengan kesadaran masyarakat terhadap pentingnya pendidikan tersebut sangat membantu untuk mengurangi pengangguran di Kota Wisata Batu.

3. Kurang Efektifnya Informasi Pasar Kerja bagi Para Pencari Kerja. Faktor lain penyebab tingginya tingkat pengangguran ialah kurang efektifnya informasi pasar kerja bagi para pencari kerja. Dalam hal penempatan tenaga kerja, pemberian pelayanan kepada ketenagakerjaan, menyelenggarakan kegiatan penempatan tenaga kerja dan perluasan kerja merupakan tugas utama dari Dinas Tenaga Kerja. Disamping itu, masyarakat juga harus meningkatkan informasi tentang pasar kerja yang diadakan oleh Dinas Tenaga Kerja sehingga mereka lebih mudah mendapatkan pekerjaan karena mereka mengetahui informasi pasar kerja yang disediakan oleh pemerintah khusunya Dinas Penanaman Modan Pelayanan Satu Pintu dan Tenaga Kerja Kota Batu.

4. Kurangnya Tingkat EQ Masyarakat. Tingkat EQ meliputi kemampuan seseorang dalam mengandalikan emosi, yang berpengaruh terhadap keterampilan berbicara/berkomunikasi, bersosialisasi, kepercayaan diri, dan sifat lainnya yang mendukung dalam hidup di masyarakat ${ }^{10}$. Kurangnya tingkat EQ masyarakat merupakan dampak dari pendidikan yang rendah. Karena seiring dengan rendahnya pendidikan yang didapat oleh seseorang akan berpengaruh terhadap EQ orang tersebut yang mengakibatkan kurangnya kepercayaan diri, kurangnya sifat sosial, kurangnya ketrampilan berbicara atau berkomunikasi dan sifat-sifat yang mendukung dalam hidup di masyarakat. Tetapi, sebaliknya jika seseorang mendapatkan pendidikan lebih tinggi, maka ia akan lebih mudah dalam bersosialisasi dan terampil dalam berkomunikasi, karena hal ini bisa kita dapat dalam dunia pendidikan khususnya di tingkat SMP, SMA dan Perguruan Tinggi.

5. Kurangnya Sosialisasi tentang Ketenagakerjaan. Hal ini juga menjadi salah satu penyebab kurangnya informasi pasar kerja bagi para pencari kerja. Kurangnya informasi pasar kerja bagi para pencari kerja dan tidak meluasnya sosialisasi pemerintah tentang ketenagakerjaan kepada pengangguran di Kota Wisata Batu merupakan faktor penyebab yang saling berkaitan karena jika si pengangguran tidak efektif dalam mencari informasi tentang pekerjaan, maka sosialisasi yang diadakan oleh pemerintah tadi juga tidak akan terdengar oleh para pengangguran tadi. Sehingga hal ini menyebabkan kurangnya sosialisasi terhadap ketenaga kerjaan ${ }^{11}$.

6. Pola Pikir Masyarakat dalam Mendapatkan Pekerjaan. Kebanyakan masyarakat di Kota Batu mempunyai pola pikir atau angan-angan tersendiri dalam mendapatkan pekerjaan. Biasanya lulusan SMA/SMK dan lulusan Sarjana yang mempunyai angan-angan mendapat pekerjaan yang tidak sulit, bekerja di kantor, duduk di depan komputer dengan gaji yang minimal setara dengan upah minimum regional (UMR). Mindset yang seperti ini harus diubah oleh masyarakat dan harusnya mereka sadar bahwa jika mereka ingin mudah dalam mencari pekerjaan, maka mereka harus melihat sekeliling lingkungan mereka peluang besar untuk dijadikan pekerjaan. Sepertihalnya, di Kota Batu dikenal akan wisatanya dan disitulah harusnya masyarakat menjadikan hal itu sebagai pekerjaan atau mata pencaharian dengan salah satunya berwira usaha.
${ }^{9}$ Hanum Oktavia, "2.400 Warga Batu Jadi Pengangguran ",

beritajatim.com, diakses dari

http://beritajatim.com/politik pemerintahan/209548/2.400 warga batu jadi pengangguran.html, pada tanggal 07 Oktober 2017 pukul 10:16 WIB

\footnotetext{
${ }^{10}$ Umiati, "Makalah Pengangguran", Zenaoke , diakses dari https://zenaoke.wordpress.com/2012/04/17/makalah-pengangguran/, pada tanggal 11 Oktober 2017 Pukul 19:48 WIB

11 Umiati, "Makalah Pengangguran", Zenaoke , diakses dari https://zenaoke.wordpress.com/2012/04/17/makalah-pengangguran/, pada tanggal 11 Oktober 2017 Pukul 19:48 WIB
} 


\section{Dampak Tingginya Tingkat Pengangguran bagi Masyarakat Kota Wisata Batu}

a) Beban Psikologis. Semakin lama seseorang menganggur semakin besar beban psikologis yang ditanggungnya. Orang yang memiliki pekerjaan berarti dia memiliki status sosial di tengah-tengah masyarakat. Seseorang yang tidak memiliki pekerjaan dalam jangka waktu lama akan merasa rendah diri (minder) karena statusnya yang tidak jelas.

b) Menimbulkan Ketidakstabilan Sosial dan Politik. Tingkat pengangguran yang tinggi menunjukkan bahwa ada banyak masyarakat yang kehilangan penghasilan. Meskipun begitu, mereka tetap dituntut untuk memenuhi kebutuhan hidup diri sendiri maupun keluarganya. Sehingga mereka akan melakukan berbagai macam usaha agar bisa memenuhi kebutuhannya ${ }^{12}$. Hal inilah yang menyebabkan kerawanan sosial dan kriminalitas seperti perampokan, pencurian, dan lain sebagainya. Tingkat pengangguran yang tinggi juga menyebabkan ketidakpuasan masyarakat sehingga memicu terjadinya demonstrasi, unjuk rasa dan huru-hara. Adanya hal ini akan berdampak terhadap keadaan politik sehingga tidak stabil.

c) Munculnya Biaya Sosial. Tingginya tingkat pengangguran akan menimbulkan pengeluaran berupa biaya-biaya sosial yng dikeluarkan oleh pemerintah setempat, seperti biaya pengadaan penyuluhan, biaya pelatihan, dan biaya keamanan sebagai akibat kecenderungan meningkatnya tindak kriminalitas ${ }^{13}$.

d) Pengangguran Menghilangkan Keterampilan Individu. Keterampilan yang dimiliki seseorang akan terus bertambah dan meningkat apabila terus digunakan. Ketika keterampilan tersebut digunakannya setiap hari sudah tentu akan ada pengalaman baru dari aktifitas yang dikerjakan. Berbeda halnya apabila keterampilan tersebut jarang digunakan setiap hari bahkan tidak pernah. Sedikit demi sedikit tingkat keterampilan tersebut akan terus berkurang bahkan lambat laun keterampilan tersebut akan menghilang. Jadi, keterampilan kerja

\footnotetext{
${ }^{12}$ Mohamad Zaenal Abidin, "Dampak Pengangguran Terhadap Individu, Masyarkat dan Perekonomian Negara", diakses dari http://karya-ilmiah.um.ac.id/index.php/ekonomipembangunan/article/view/35988, pada tanggal 14 Oktober 2017 pukul 15:30 WIB

13 Mohamad Zaenal Abidin, "Dampak Pengangguran Terhadap Individu, Masyarkat dan Perekonomian Negara", diakses dari http://karya-ilmiah.um.ac.id/index.php/ekonomipembangunan/article/view/35988, pada tanggal 14 Oktober 2017 pukul 15:30 WIB
}

yang dimiliki seseorang akan menghilang dengan sendirinya apabila tidak digunakan untuk bekerja.

e) Pengangguran Menghilangkan Mata Pencaharian Dan Pendapatan Individu. Apabila seseorang menganggur maka sudah tentu ia tidak mempunyai mata pencaharian. Dengan tidak memiliki mata pencaharian, maka ia juga kehilangan sumber pendapatan.

\section{Respon Pemerintah terhadap Masalah Tingginya Tingkat Pengangguran di Kota Wisata Batu}

a) Dinas Penanaman Modal Pelayanan Terpadu Satu Pintu dan Tenaga Kerja mencanangkan program"Kegiatan Pembinaan dan Pelatihan Ketrampilan Kerja bagi Tenaga Kerja dan Masyarakat"

Gambar. 2: Foto Peserta Kegiatan Pembinaan dan Pelatihan Ketrampilan Kerja bagi Tenaga Kerja Masyarakat"14

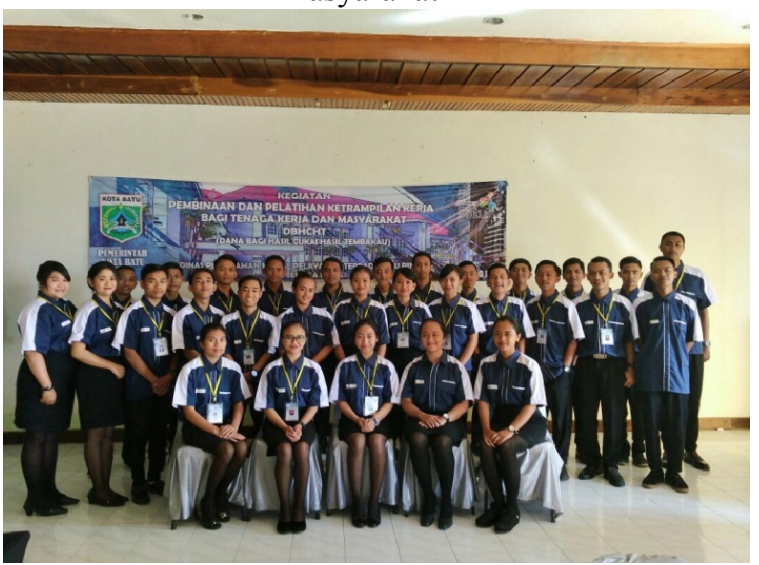

Sumber : http://bpm.batukota.go.id/

Kegiatan Pembinaan Dan Pelatihan Ketrampilan Kerja Bagi Tenaga Kerja Dan Masyarakat dilaksanakan setiap hari senin-jum'at selama 1 (satu) bulan. Peserta pelatihan sebanyak 30 orang peserta yang terdiri dari lulusan SMA dan SMK di Kota Batu yang telah lolos dalam seleksi recruitment. Kegiatan ini merupakan program pelatihan pada Bidang Penempatan dan Pelatihan Tenaga Kerja, Dinas Penanaman Modal Pelayanan Terpadu Satu Pintu dan Tenaga Kerja Kota Batu. Pada pelatihan kerja ini mengajarkan berbagai kemampuan dasar dalam bidang perhotelan seperti Making bed, dan Front Office dengan mendatangkan instruktur-instruktur yang berkompeten dalam bidang pelatihan kerja maupun dalam bidang perhotelan. Upaya pemerintah dengan mencanangkan program "Kegiatan Pembinaan dan Pelatihan Ketrampilan Kerja bagi Tenaga Kerja dan

\footnotetext{
14 "Kegiatan Pembinaan Dan Pelatihan Ketrampilan Kerja Bagi Tenaga Kerja Dan Masyarakat", Dinas Penanaman Modal Pelayanan Terpadu Satu Pintu dan Tenaga Kerja, diakses dari http://bpm.batukota.go.id/dpmptsptk/web/detail/67/kegiatan_pembinaan dan pelatihan ketrampilan kerja bagi tenaga kerja dan masyarakat , pada tanggal 14 Oktober 2017 pukul 10:04 WIB.
} 
Masyarakat" ini cukup baik karena dengan adanya kegiatan ini sangat membantu untuk meningkatkan SDM bagi calon tenaga kerja supaya memiliki daya saing dan mampu bersaing di pasar Kerja.

b) Dinas Sosial dan Tenaga Kerja Kota Batu bekerja sama dengan Disperindag. Dapat dilihat dari kutipan beritajatim.com ${ }^{15}$

Guna meminimalisir jumlah pengangguran, maka Pemkot Batu terus melakukan sosialisasi dan informasi mengenai lapangan pekerjaan melalui berbagai media. "Kami juga bekerjasama dengan Disperindag Kota Batu yang mempunyai link mengenai lapangan pekerjaan baru," imbuhnya.

Dari kutipan diatas responsivitas pihak Pemkot Batu sendiri terbilang sangat baik. Apalagi kerja sama antara Dinas Sosial dan Tenaga kerja dengan Disperindag bisa membantu mengurangi pengangguran dengan cara memberikan sistem informasi pasar kerja bagi masyarakat Kota Batu, karena Disperindag juga memegang banyak link informasi pasar kerja sehingga hal ini juga bisa mengurangi tingginya tingkat pengangguran di Kota Batu itu sendiri.

c) Kegiatan Pembinaan Pelayanan Penempatan Tenaga Kerja Antar Daerah (AKAD) dan Antar Kerja Lokal (AKL)

Gambar. 3: Peserta Kegiatan Pembinaan Pelayanan

Penempatan Tenaga Kerja Antar Daerah (AKAD) dan Antar Kerja Lokal (AKL)

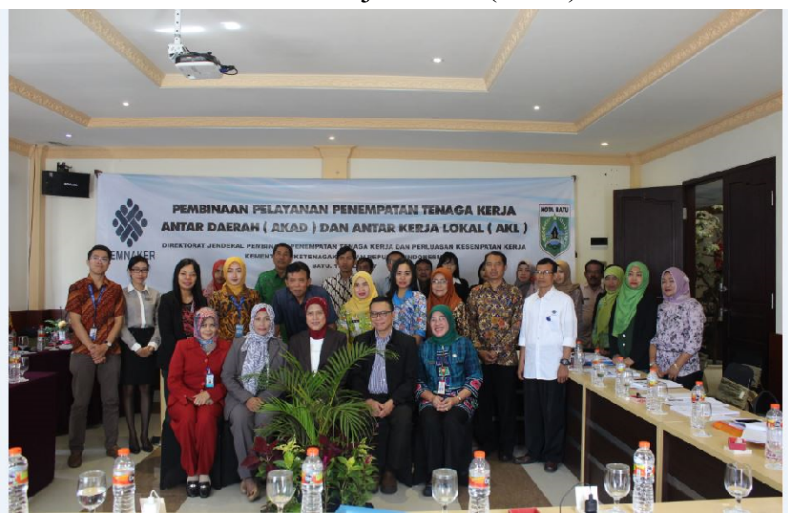

Sumber : http://bpm.batukota.go.id/

Kegiatan Pembinaan Pelayanan Penempatan Tenaga Kerja Antar Daerah (AKAD) Dan Antar Kerja Lokal (AKL) dilaksanakan pada hari kamis, tanggal 13 juli 2017 bertempat di Hotel Zam Zam Kota Batu. Tujuan kegiatan ini untuk melakukan pembinaan serta memberikan pelayanan penempatan tenaga kerja kepada

\footnotetext{
15 Hanum Oktavia, "2.400 Warga Batu Jadi Pengangguran", beritajatim.com, diakses dari

http://beritajatim.com/politik pemerintahan/209548/2.400_warga batu jadi pengangguran.html, pada tanggal 11 Oktober 2017 pukul 20:10
} WIB pencari kerja maupun pemberi kerja dalam sistem antar kerja yang meliputi fungsi pelayanan informasi pasar kerja, pelayanan penyuluhan dan bimbingan jabatan dan pelayanan perantara kerja. Kegiatan ini diikuti oleh 25 orang peserta terdiri dari bursa kerja kursus, lembaga pelatihan kerja dan pemberi kerja / pengusaha ${ }^{16}$. Kegiatan penempatan tenaga kerja antar daerah dan lokal ini juga cukup bagus untuk mengatasi tingginya tingkat pengangguran di Kota Wisata Batu karena dengan adanya kegiatan ini para pencari kerja bisa mendapatkan informasi pasar kerja dan pekerjaan dari luar Kota maupun antar daerah sehingga memudahkan penempatan tenaga kerja bagi para pencari kerja dan lebihnya lagi pihak dinas sendiri yang mengayomi sehingga lebih jelas dan terorganisir.

d) Motivasi dan Manajemen Usaha Mandiri Sektor Informal

Gambar. 4: Foto Dokumentasi Motivasi dan Manajemen Usaha Mandiri Sektor Informal

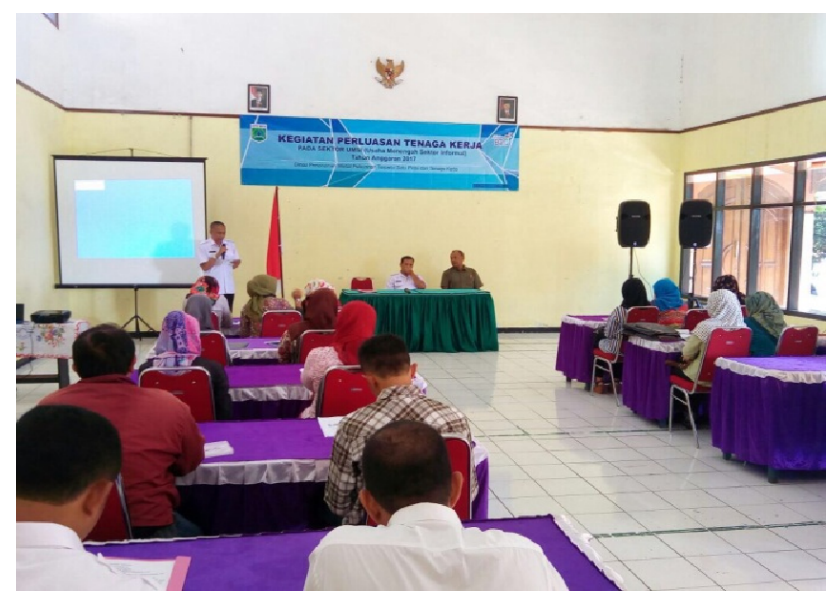

Sumber : http://bpm.batukota.go.id/

Pada tanggal 15 Maret s/d 16 Maret 2017 diadakan kegiatan Perluasan Tenaga Kerja Pada Sektor UMSI (Usaha Mandiri Sektor Informal) berupa pelatihan manajemen dan motivasi usaha yang dilaksanakan oleh Dinas Penanaman Modal Pelayanan Terpadu Satu Pintu dan Tenaga Kerja Kota Batu ( DPM PTSP \& Naker) di Kantor Kelurahan Songgokerto Kota Batu ${ }^{17}$. Dalam kegiatan tersebut yang menjadi narasumber adalah Bapak Juli Suprianta dari UPT Pengembangan Produktivitas

\footnotetext{
16 "Kegiatan Pembinaan Pelayanan Penempatan Tenaga Kerja Antar Daerah (AKAD) dan Antar Kerja Lokal (AKL)", Dinas Penanaman Modal Pelayanan Terpadu Satu Pintu dan Tenaga Kerja, diakses dari http://bpm.batukota.go.id/dpmptsptk/web/detail/66/kegiatan_pembinaan pelayanan penempatan tenaga kerja antar daerah \%28akad\%29 dan antar kerja lokal \%28ak1\%29, pada tanggal $1 \overline{4}$ Oktober 2017 pukul 11:24 WIB

17 "Motivasi Dan Manajemen Usaha Mandiri Sektor Informal”, Dinas Penanaman Modal Pelayanan Terpadu Satu Pintu dan Tenaga Kerja, diakses

dari

http://bpm.batukota.go.id/dpmptsptk/web/detail/52/motivasi dan manaj emen usaha mandiri sektor informal, pada tanggal 14 Oktober 2017 pukul 11:41 WIB
} 
Tenaga Kerja Dinas Tenaga Kerja dan Transmigasi Pemerintah Provinsi Jawa Timur. Pada hari pertama dilakukan seminar tentang manajemen dan motivasi usaha. Pada hari kedua dilakukan kunjungan usaha pada Rakha Bakery di Desa Torongrejo Kota Batu. Kegiatan Perluasan Tenaga Kerja Pada Sektor UMSI (Usaha Mandiri Sektor Informal) diharapkan dapat meningkatkan pemahaman manajemen usaha dan motivasi usaha kepada pelaku usaha di Kota Batu ${ }^{18}$. Kegiatan ini juga diperuntukan masyarakat Kota Batu yang ingin berwirausaha. Berwirausaha atau membangun usaha sendiri merupakan salah satu cara untuk mengurangi tingginya tingkat pengangguran. Selain bisa menjadi mata pencaharian tetap disamping itu juga para wirausahawan juga dapat membuka peluang pekerjaan bagi pengangguran yang lain, sehingga menolong pemerintah dalam mengurangi angka pengangguran.

e) Dinas Sosial dan Tenaga Kerja Kota Batu menggelar job market fair atau pameran bursa kerja. Hal ini dapat diketahui dari kutipan Beritajatim.com

Sedangkan untuk pengangguran aktif, ungkap Alfian, Dinsosnaker berupaya menyalurkan ke tempat kerja di berbagai perusahaan. Di antaranya dengan menggelar mini job fair yang dibuka di kantor Kecamatan. Hal itu dilakukan untuk lebih mendekatkan tempat mencari kerja dengan asal tenaga kerja. "Seperti mini job fair di kantor kecamatan Batu ini, sebelumnya juga sudah kami gelar mini job fair di kecamatan Junrejo dan kecamatan Bumiaji. Warga kota Batu selalu mendapatkan prioritas oleh perusahaan peserta mini job fair," tutur Alfian.

Dari penjelasan diatas, dengan diadakannya mini job fair dapat menyerap tenaga kerja dan mengurangi tingkat pengangguran. Manfaat untuk perusahaan antara lain mereka dapat menemukan banyak kandidat atau calon karyawan untuk perusahaan mereka ${ }^{19}$. Sedangkan manfaat dari Job Fair untuk para pencari kerja merupakan tempat menemukan berbagai pekerjaan yang cukup potensial. Dimana mereka bisa memasukkan lamaran langsung ke masing-masing perusahaan. Informasi pekerjaan yang di butuhkan pun lebih akurat dan juga terdapat banyak pilihan jenis posisi pekerjaan. Tingginya tingkat

\footnotetext{
18 "Motivasi Dan Manajemen Usaha Mandiri Sektor Informal”, Dinas Penanaman Modal Pelayanan Terpadu Satu Pintu dan Tenaga Kerja, diakses dari http://bpm.batukota.go.id/dpmptsptk/web/detail/52/motivasi dan manaj emen usaha mandiri sektor informal, pada tanggal 14 Oktober 2017 pukul 11:41 WIB

19 Hanum Oktavia, "2.400 Warga Batu Jadi Pengangguran ", beritajatim.com, diakses dari
}

http://beritajatim.com/politik pemerintahan/209548/2.400 warga batu jadi pengangguran.html, pada tanggal 07 Oktober 2017 pukul 10:16 WIB pengangguran di Kota Wisata Batu merupakan tanggung jawab masyarakat sendiri dan Pemerintah Kota khususnya Dinas Sosial dan Tenaga Kerja. Seharusnya masyarakat aktif dalam menggali informasi di pasar kerja dengan cara mengikuti sosialisasi khususnya yang diadakan oleh Dinas Sosial dan Tenaga Kerja. Sedangkan disisi Pemerintah, khususnya Dinsosnaker mengembangkan dalam bentuk pelayanan seperti diadakannya pelatihan tenaga kerja dan sebagainya.

\section{KESIMPULAN}

Responsivitas Dinas Penanaman Modal Pelayanan Terpadu Satu Pintu dan Tenaga Kerja Kota Wisata Batu bisa dikatakan sudah sangat baik dalam menangani masalah tingginya tingkat pengangguran. Tingginya tingkat pengangguran di Kota Wisata Batu di sebabkan oleh beberapa faktor, yaitu: pendidikan yang rendah, kurangnya ketrampilan, kurang efektifnya informasi pasar kerja bagi para pencari kerja, kurangnya tingkat EQ masyarakat, kurangnya sosialisasi tentang ketenagakerjaan, pola pikir masyarakat dalam mendapatkan pekerjaan, rasa malas dan ketergantungan diri pada orang lain. Disisi lain, tingginya tingkat pengangguran juga berdampak bagi masyarakat. Dampakdampak tersebut ialah beban psikologis, menimbulkan ketidakstabilan antara sosial dan politik, munculnya biaya sosial, pengangguran menghilangkan keterampilan individu, serta pengangguran menghilangkan mata pencaharian dan pendapatan individu.

Untuk mengurangi tingkat pengangguran, maka harus ada dari Pemerintah dan Dinas Penanaman Modal Pelayanan Terpadu Satu Pintu dan Tenaga Kerja Kota Wisata Batu. Respon dan upaya-apaya Pemerintah Kota Batu dalam menangani masalah tingginya tingkat pengangguran di Kota Wisata Batu yaitu: dengan direncanakan dan diadakannya "Kegiatan Pembinaan dan Pelatihan Ketrampilan Kerja bagi Tenaga Kerja dan Masyarakat" oleh Dinas Penanaman Modal Pelayanan Terpadu Satu Pintu dan Tenaga Kerja Kota Wisata Batu, dijalinnya hubungan kerja sama antara Dinas Sosial dan Tenaga Kerja Kota Batu dengan Disperindag, Kegiatan Pembinaan Pelayanan Penempatan Tenaga Kerja Antar Daerah (AKAD) dan Antar Kerja Lokal (AKL), Motivasi dan Manajemen Usaha Mandiri Sektor Informal, dan job market fair atau pameran bursa kerja yang digelar oleh Dinas Sosial dan Tenaga Kerja Kota Batu. 


\section{SARAN}

Dari seluruh penjabaran pembahasan di atas, penulis mengajukan beberapa saran, yaitu:

a) Meningkatkan mobilitas tenaga kerja dan memperbaiki pasar tenaga kerja, karena seiringnya dengan perkembangan dan pembangunan di Kota Wisata batu harusnya dapat mengurangi tingginya tingkat pengangguran dikota tersebut.

b) Dinas Penanaman Modal Pelayanan Terpadu Satu Pintu dan Tenaga Kerja Kota Wisata Batu hendaknya lebih aktif dan lebih luas dalam melakukan sosialisasi tentang informasi pasar kerja bagi para pencari kerja.

c) Masyarakat hendaknya merubah mindset dalam mencari pekerjaan, karena berangkat dari kesadaran bahwa setiap manusia sesungguhnya memilki potensi dalam dirinya namun sering tidak menyadari dan mengembangkan secara optimal. Dengan demikian, setiap pribadi sanggup mengaktualisasikan potensi terbaiknya dan dapat menciptakan kehidupan yang lebih baik, bernilai dan berkualitas bagi dirinya sendiri maupun masyarakat luas.

d) Pemerintah Kota khususnya Dinas Penanaman Modal Pelayanan Terpadu Satu Pintu dan Tenaga Kerja Kota Wisata Batu hendaknya lebih mendomisilikan tenaga kerja dari Kota Batu sendiri dari pada warga luar kota dalam mengambil angkatan kerja.

e) Pemerintah Kota Batu dan masyarakat harus bersinergi dalam meningkatkan wawasan, pengetahuan dan kemampuan jiwa kewirausahaan kepada Usaha Kecil dan Menengah (UKM), yaitu berupa bimbingan teknis, manajemen, dan memberikan bantuan modal lunak jangka panjang, serta perluasan pasar dari pemerintah dan masyarakat harus sangat berperan aktif dan merespon baik hal tersebut.

\section{DAFTAR PUSTAKA}

Agustino, Leo. 2006. Dasar-Dasar Kebijakan Publik. Bandung : CV. Alfa Beta.

Arikunto, Suharsimi. 2010. Prosedur Penelitian: Suatu Pendekatan Praktik. Jakarta: Rineka Cipta.

Arikunto, Suharsimi. 1990. Manajemen Penelitian. Jakarta: Rineka Cipta.

Dwiyanto, Agus dkk. 2008. Mewujudkan Good Governance Melalui Pelayanan Publik. Gajah Mada University Press: Yogyakarta.

Dwiyanto, Agus dkk. 2006. Reformasi Birokrasi Publik di Indonesia. Gajah Mada University Press: Yogyakarta.

Dwiyanto, Agus. Penilaian kinerja Organisasi Pelayanan Publik pada Seminar Kinerja Organisasi Sektor Publik, Kebijakan dan Penerapannya,
Jurusan Ilmu Administrasi Negara, Fakultas Ilmu Sosial dan Politik Universitas Gadjah Mada. Yogyakarta: 20 Mei 1995.

Koentjaraningrat. 1991. Metode-Metode Penelitian Masyarakat. Jakarta: PT. Raja Grafindo Persada.

Marius, Jelamu Ardu. Memecahkan masalah Pengangguran di Indonesia. Makalah dipresentasikan di IPB pada April 2004.

Mayer, Robert R. \& Greenwood, Ernest. 1984. Rancangan Penelitian Kebijakan Sosial. Jakarta: CV Rajawali.

Moleong, Lexy, J. 2002. Metodologi Penelitian Kualitatif. Bandung: PT. Remaja Rosada Karya.

Pitartono. 2012. Analisis Tingkat Pengangguran Di Jawa Tengah Tahun 1997-2010. Skripsi S1, Program Sarjana Fakultas Ekonomika dan Bisnis Universitas Diponegoro Tahun 2012.

Siagian, P Sondang. 2016. Filsafat Administrasi. Jakarta: PT. Bumi Aksara. 